\title{
Upper crustal structure under Jingtai-Hezuo profile in Northeastern Tibet from topography-dependent eikonal traveltime tomography
}

\author{
Ting Ma $\cdot$ Zhongjie Zhang $\cdot$ Peng Wang $\cdot$ \\ Yingkang Li
}

Received: 26 July 2013/Accepted: 4 November 2013/Published online: 3 January 2014

(c) The Seismological Society of China, Institute of Geophysics, China Earthquake Administration and Springer-Verlag Berlin Heidelberg 2013

\begin{abstract}
The Northeastern Tibetan plateau records Caledonian Qilian orogeny and Cenozoic reactivation by continental collision between the Indian and Asian plates. In order to provide the constraint on the Qilian orogenic mechanism and the expansion of the plateau, wide-angle seismic data was acquired along a $430 \mathrm{~km}$-long profile between Jingtai and Hezuo. There is strong height variation along the profile, which is dealt by topography flattening scheme in our crustal velocity structure reconstruction. We herein present the upper crustal P-wave velocity structure model resulting from the interpretation of first arrival dataset from topography-dependent eikonal traveltime tomography. With topography flattening scheme to process real topography along the profile, the evenness of ray coverage times of the image area (upper crust) is improved, which provides upper crustal velocity model comparable to the classic traveltime tomography (with model expansion scheme to process irregular surface). The upper crustal velocity model shows zoning character which matches
\end{abstract}

Zhongjie Zhang (1964-2013)

T. Ma $(\bowtie) \cdot$ Z. Zhang

State Key Laboratory of Lithospheric Evolution, Institute of Geology and Geophysics, Chinese Academy of Sciences, Beijing 100029, China

e-mail: grace@mail.iggcas.ac.cn

T. Ma $\cdot$ P. Wang

University of Chinese Academy of Sciences, Beijing 100049,

China

P. Wang

Guangzhou Institute of Geochemistry, Chinese Academy of Sciences, Guangzhou 510640, China

Y. Li

Geological Material Center, China Geology Survey,

Yanjiao 065201, Hebei, China with the tectonic division of the Qaidam-Kunlun-West Qinling belt, the Central and Northern Qilian, and the Alax blocks along the profile. The resultant upper crustal P-wave velocity model is expected to provide important base for linkage between the mapped surface geology and deep structure or geodynamics in Northeastern Tibet.

Keywords Northeastern Tibet - Wide-angle seismic profiling · Upper crust · Velocity · Topographydependent eikonal traveltime tomography

\section{Introduction}

The Tibetan plateau covers a vast area (about 2.5 million $\mathrm{km}^{2}$ ), and is characterized by a high topography (with an average altitude of 4,000 $\mathrm{m}$ above sea level) and a thick crust (with an average crustal thickness of 60-75 km). Both the process itself and the mechanism of the crustal thickening, as well as the lateral expansion of the plateau are among the key topics in the study of the continent-continent collision involved in forming the Tibetan plateau (Yin and Harrison 2000). The crustal thickening process may be related to the subduction, collision, and postcollisional convergence of the PaleoTethys and NeoTethys plate and the associated continental lithosphere (Tapponnier et al. 2001; Royden et al. 2008). Numerous crustal thickening models have been proposed, such as wholesale underthrusting (Argand 1924), the injection of the crust of India beneath that of Asia beneath South Tibet (Himalaya, Lhasa terranes) (Zhao and Morgan 1985), channel flow or extrusion of the middle crust in Himalaya (Beaumont et al. 2004; Klemperer 2006) to uplift the plateau and middle/lower crustal channel flow (Royden et al. 2008), or tectonic escape (Burchfiel et al. 1989; Tapponnier et al. 2001; Zhang et al. 2010) in East Tibet, causing 


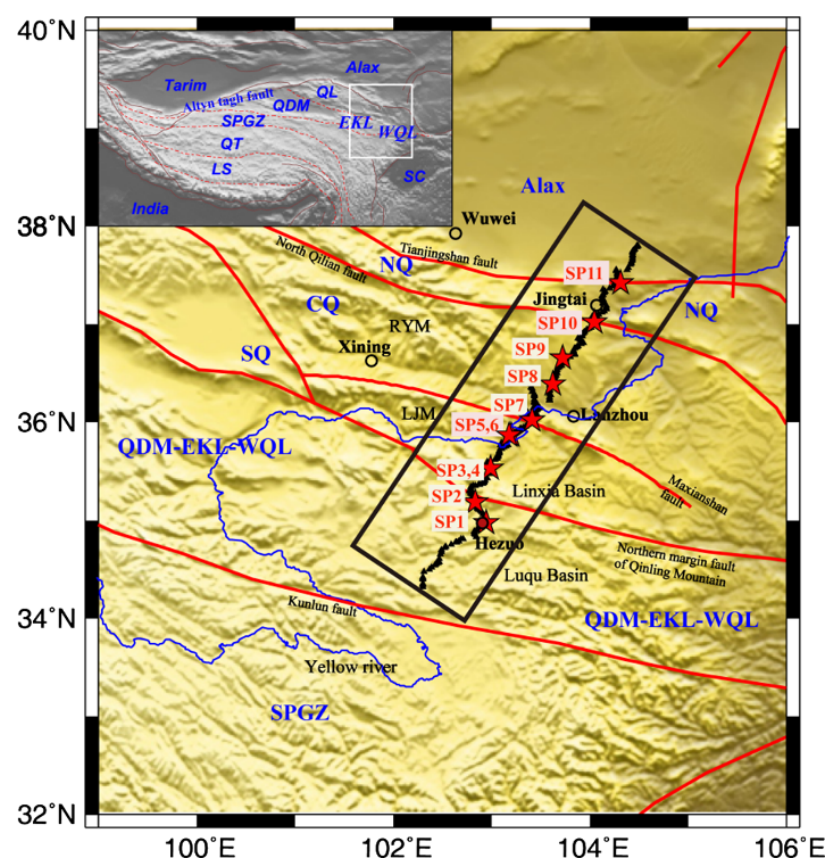

Fig. 1 Tectonic map of the Northeastern Tibet with wide-angle seismic experiment (Zhang et al. 2013). Inset geographic position of the Northeastern Tibet. The red stars represent positions of the seismic sources, and the triangles denote receivers. India India plate, Tarim Tarim basin, Alax Alax depression in the western North China craton, $L S$ Lhasa block; $Q T$ Qiangtang block, SPGZ Songpan-Ganzi block, $Q D M$ Qaidam basin, $Q L$ Qilian block, $E K L$ East Kunlun orogenic belt, $W Q L$ West Qinling orogenic belt, $Q D M-E K L-W Q L$ Qaidam-East Kunlun-West Qinling block, $S Q$ South Qilian block, $C Q$ Central Qilian block, $N Q$ Northern Qilian block, $R Y M$ Riyuan mountain, LJM Laji mountain

the lateral expansion of the plateau (Klemperer 2006). All these models can be categorized into distributional shortening/thickening of the Asian crust (Burke and Dewey 1973; Molnar and Tapponnier 1978; Mattauer 1986; Molnar and Lyon-Caen 1988) and the homogeneous shortening/thickening of the Asian lithospheric mantle with convective removal of its lithospheric bottom (Molnar et al. 1993; England and Houseman 1986, 1989; Dewey et al. 1988; Zhang et al. 2010). It should be mentioned that most of these models have been proposed from tectonic (Yin and Harrision 2000) or geophysical observations (Zhao and Nelson 1993; Owens and Zandt 1997) in the Himalayas and within the plateau bounded by Main Boundary Thrust (to the south) and the Kunlun fault (to the north), with more interest being paid to the shallow characteristics and deep structure south to the Kunlun fault (i.e., at its northern edge) (Li et al. 2003; Wang et al. 2005; Liu et al. 2006; Jia et al. 2010; Zhang et al. 2011; Tian and Zhang 2013). However, to the north of the Kunlun fault, from the Tarim, Gobi, and Alax platforms (Fig. 1), the fold-thrust belts along the northeastern edge of the Tibetan Plateau (such as the Henan Shan, Qilian Shan, and Liupan Shan) are presently undergoing shortening as they are incorporated into the plateau (Meyer et al. 1998).
In tectonic terms, the Northeastern Tibetan plateau is a mosaic of multiple terrains and island-continental arcs (Xu et al. 2001). Lying in the northern margin of the Tibetan plateau, the Qilian Caledonian orogenic belt form a WNWESE trending belt with a length of about $800 \mathrm{~km}$ and a width of $400 \mathrm{~km}$ (Xu et al. 2001). This belt is bounded to the north by the Hexi Corridor, by the Qaidam basin to the south, by the west Qinling mountains to the east and by the Altyn Tagh fault to the west (Xu et al. 2001). The Northeastern Tibetan Plateau can be divided into five tectonic units; these are, from north to south, the Alax Block, the North Qilian oceanic-type Suture Zone, the Qilian Block, the North Qaidam continental-type UHPM Belt (CNQ) and the Qaidam-Kunlun-West Qinling Block (Fig. 1). The discoveries of the HP/LT metamorphic belt and the North Qaidam UHP metamorphic belt in Northeastern Tibet (Yang et al. 1998, 2002a; Wei et al. 2009; Yin et al. 2007a, b) provide important constraints on our understanding of the Caledonian orogeny. It is now accepted that the Qilian terrane has a Caledonian arc-continent orogeny. Essentially there are three possible orogeny mechanisms, namely (1) the paired subduction model of Yang et al. (2002b), (2) the transition model from oceanic subduction to continental collision of Song et al. (2006) or (3) the multiple-accretionary model of Xiao et al. (2009). The deep seismic sounding of the crustal structure in Northeastern Tibet provides important constraints to deepen our understanding of the Caledonian orogeny, as well as our understanding of the growth of the plateau.

The expansion of the plateau is well understood with GPS measurements across Tibet in past years (Gan et al. 2007). The available mechanisms for the lateral expansion of the Northeastern Tibetan plateau (to 2.5-3.0 million $\mathrm{km}^{2}$ ) include (1) the northward thrusting of the upper crust (Tapponnier et al. 1990; Métivier et al. 1998); (2) tectonic escape at the crustal/lithospheric scale from lateral shearing of the Kunlun and Altyn faults (Tapponnier et al. 2001), (3) lower crustal channel flow (Royden et al. 2008) and (4) southward subduction of North China craton (Yin 2010) from geological mapping, balanced reconstruction, tectonic, geochemical, and topography data. The gradual northeastward decrease in elevation across the northeastern border of the Tibetan plateau may be signature that much of the upper crust forms a northeastward tapering wedge decoupled from the underlying lowermost crust and mantle lithosphere along a large lower to mid-crustal decollement dipping at a shallow angle to the southwest (Tapponnier et al. 1990, 2001). It is obvious that the crustal structure across the northeastern part of the Tibetan plateau can provide constraints on evaluation of these models about the northward growth of the plateau.

Lateral variation in topography is present in Northeastern Tibet, which should be considered in our crustal velocity structure tomography. As illuminated by Fig. 2, 
(a)

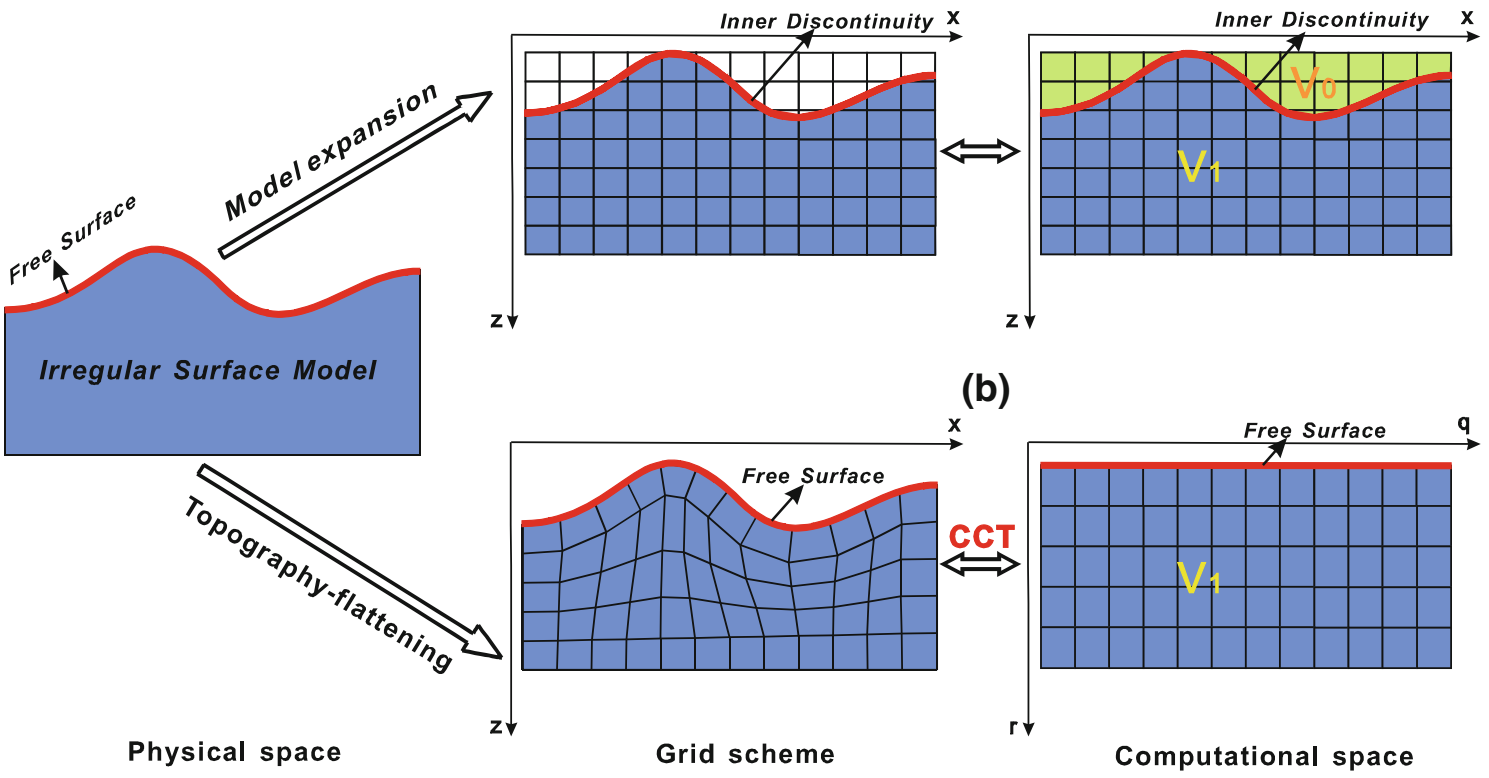

Fig. 2 Schematic diagram of two irregular surface treatments (Ma and Zhang 2013a): a model expansion scheme. The gridded physical model space is expanded to a regular computational space, and the irregular surface is treated as an inner discontinuity, b irregular surface flattening scheme. The irregular surface is flattened by the transformation from the Cartesian to curvilinear coordinates

there are two schemes to deal with the topography issue in the calculation of traveltime and seismic ray path. Classic model expansion scheme is widely and effectively used till now (Vidale 1988, 1990; Reshef 1991; Hole 1992). As an alternative way, topography-dependent traveltime tomography scheme (Ma and Zhang 2013b) was developed with a first-arrival ray-path tracking (Ma and Zhang 2013a) and the topography-dependent eikonal equation solver (Lan and Zhang 2013a, b). With the introduction of transformation between the curvilinear and Cartesian coordinate systems, the calculation of first-arrival traveltimes and traveltime gradient for calculating ray paths in a gridded physical space (confined by an irregular surface) was converted into a calculation in a computational space (confined by a flattened surface). In this way, the irregular surface was kept as free surface (Fig. 2b) in contrast to the model expansion scheme where the irregular surface is converted to inner discontinuity in the expanded space (Fig. 2a). This change of the irregular surface from free surface to inner discontinuity may produce some unexpected result while keeping some expected issue. The expected one is the stairstep representation of the irregular surface using rectilinear grids to the discretization. The unexpected one is the resultant spurious rays. In this study, we will present the results of first-arrival traveltime tomography with the topography-dependent eikonal tomography scheme (Ma and Zhang 2013b).

For the completeness of the study, we will summarize seismic observation and topography-dependent eikonal traveltime tomography, and finally present the upper crustal structure along the Jingtai-Hezuo profile in the Northeastern Tibet.

\section{Brief description of seismic experiment in Northeastern Tibet}

The P-wave seismic data used in this study were acquired from a $430 \mathrm{~km}$-long wide-angle reflection/refraction profile (Fig. 1) in April and May of 2009 by the Institute of Geology and Geophysics of the Chinese Academy of Sciences, and the Geophysical Exploration Center of the China Earthquake Administration. The holes were drilled and explosives were fired by the 6th Geophysical Abridge in the Huadong Petroleum Geology Bureau of the Sino-Petroleum Exploration Company (SINOPEC). The profile, with an azimuth near $\mathrm{N} 45^{\circ} \mathrm{E}$, runs between Hezuo and Jingtai, which is at the southern margin of Alax block, Gansu Province (Fig. 1). A total of 11 shots were fired with an average shot spacing interval of $50 \mathrm{~km}$. Two shots SP1 and SP2 (near Hezuo, Fig. 1) were fired south to the northern margin of the western Qinling Mountains (in the Qaidam-Kunlun-West Qinling block); eight shots (SP3, SP4, SP5, SP6, SP7, SP8, SP9, and SP10 in Fig. 1) were fired in the Qilian terrane. SP11 is located at the northern margin fault of Qilian Mountains and Tianjingshan fault belt. A total of 200 portable three-component digital seismographs were used to acquire the seismic data along the inline profile. The station spacing was $2 \mathrm{~km}$. In order to save space, Fig. 3 shows only four P-wave seismic shot gathers, and the others can be observed in Zhang et al. 

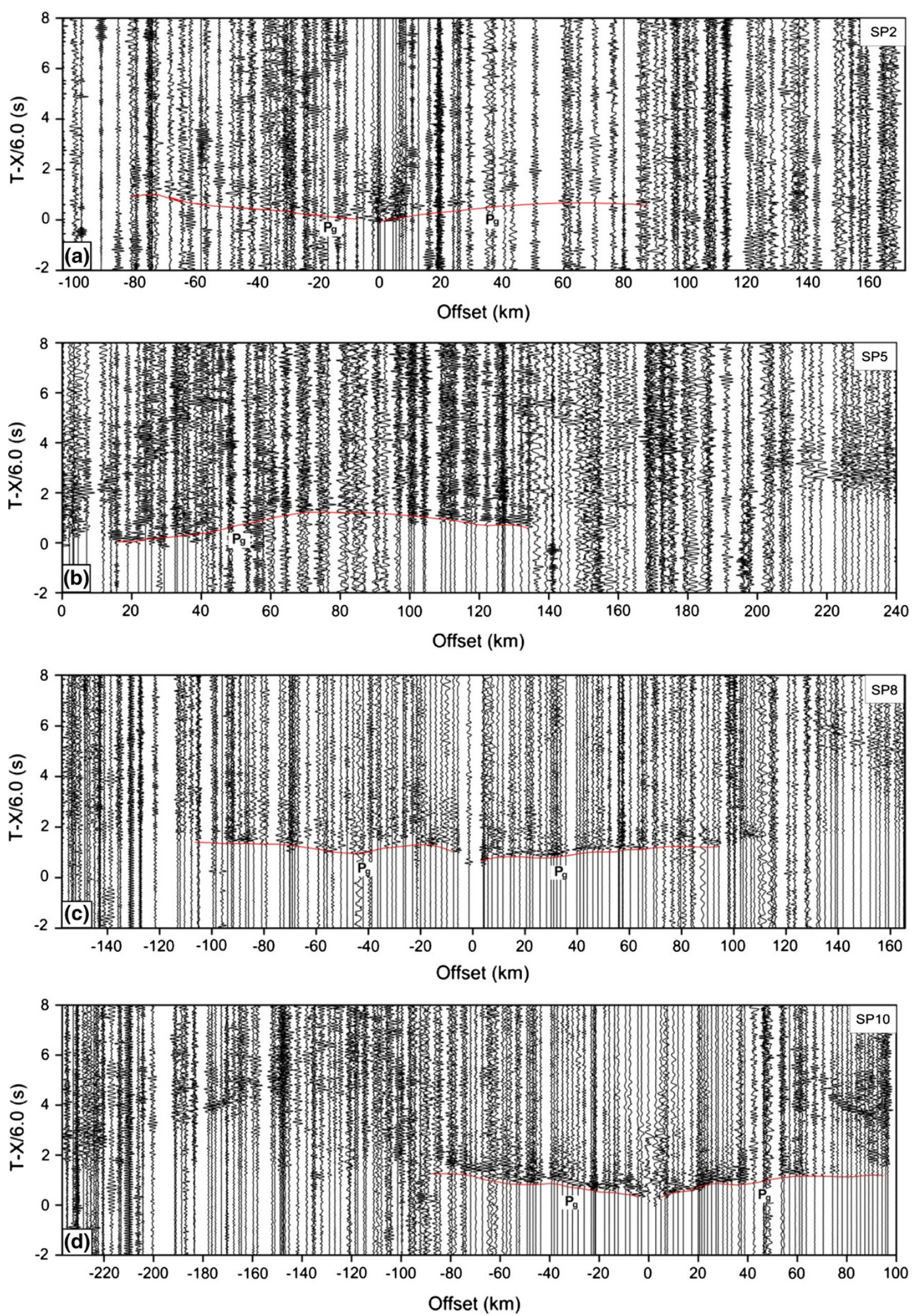

Fig. 3 P-wave seismic sections for observed data for SP2, SP5, SP8 and SP10. a Shot SP2 at Wangger. b Shot SP5at Sanyuan. c Shot SP8 at Shuping and $\mathbf{d}$ Shot SP10 at Jingtai. The seismic data is filtered using a 1-10 Hz bandpass filter. The red lines denote the picked data (Pg-phase) 


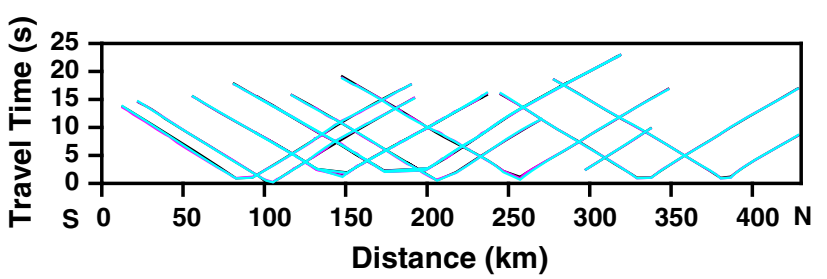

Fig. 4 Match results of first-arrival traveltime. Black, pink and light blue lines denote the picked, calculated by Hole (1992) and topography-dependent eikonal traveltime tomography, respectively

(2013). In this wide-angle seismic experiment, the first arrivals as refractions above the crystalline basement of the crust (Pg-phase) can easily be correlated. Figure 4 displays the traveltime-offset relationship for Pg event of these shot gathers. Before the upper crustal P-wave velocity structure was present, we will summarize topography-dependent eikonal traveltime tomography used in the data interpretation.

\section{Topography-dependent eikonal traveltime tomography}

For a seismic source located at position at irregular surface (represented by white star) (Fig. 5), there is an array of seismometers ( $n$ in total) installed to receive seismic signal triggered by the source. The first Pg arrivals from these seismometers ( $\leq n$, depending on the observed offset ranges of the Pg events in the seismic experiment) are used to construct the upper crustal velocity structure by using the first-arrival traveltime tomography.

For the geological model as in Fig. 5, seismic velocity is $V(x, z)$, and $T(x, z)$ is the traveltime field. $l[s(x, z)]$ denotes the ray path, and $s(x, z)$ is the slowness, that is, the reciprocal velocity. The seismic traveltime can be written as (Nolet 1987)

$T=\int_{l[s, z)]} s(x, z) \mathrm{d} l$.

This relationship (1) is nonlinear. Supposing a small slowness perturbation about a reference slowness $s_{0}(x, z)$, that is $s(x, z)=s_{0}(x, z)+\delta s(x, z)$. According to Fermat's principle, the traveltime perturbation can be written as

$\delta T=T-T_{0}=\int_{l\left[s_{0}(x, z)\right]} \delta s(x, z) \mathrm{d} l$.

Equation (2) is a linear relationship between traveltime residual and slowness perturbation that can be used for inversion. Therefore, it is a linearization of the nonlinear problem and iterations are required. Transforming Eq. (2) into the matrix form

$L \Delta S=\Delta T$

$L$ is the ray paths matrix, $\Delta S$ is the slowness perturbation matrix, and $\Delta T$ is the traveltime residual matrix. Therefore, after we obtain the traveltime residual and ray paths, the slowness perturbation can be calculated by solving the Eq. (3).

For a linear problem, $\delta T_{i}$ have a relationship with the model $\delta s(x, z)$ through a form (Hole 1992)

$\delta T_{i}=\iint \delta s(x, z) g_{i}(x, z) \mathrm{d} x \mathrm{~d} z, i=1,2, \cdots, M$,

where the functions $g_{i}(x, z)$ are data kernels. In order to perform a linear inversion, the data are given by

$\delta T_{i}=\sum_{j=1}^{N} \alpha_{j} \Gamma_{i j}$

where $\Gamma_{i j}=\iint h_{j}(x, z) g_{i}(x, z) \mathrm{d} x \mathrm{~d} z . \quad h_{j}(x, z) \quad$ are basis functions, and the model is parameterized by $\delta s(x, z)=$ $\sum_{j=1}^{N} \alpha_{j} h_{j}(x, z)$.

In tomography, the problem contains the solution of the Eq. (5) to find the parameters $\alpha_{j}$. For the inversion schemes, there are some iterative routines such as the algebraic reconstruction technique, simultaneous iterative reconstruction technique, conjugate gradient methods, and LSQR (e.g., Dines and Lytle 1979; Humphreys et al. 1984; Peterson et al. 1985; Scales 1987; Paige and Saunders 1982). The backprojection algorithm (Hole 1992) reduces the computational costs and allows the model to be densely sampled. We herein use backprojection scheme (Hole 1992) to solve the linearized equation in topography-dependent eikonal

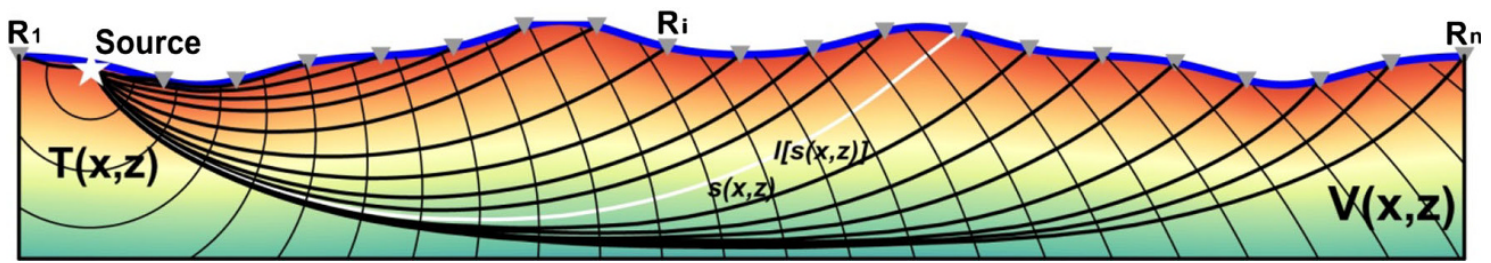

Fig. 5 The schematic diagram of seismic survey. The white star denotes the source and the inverted gray triangles denote the receivers located on the irregular surface. Traveltime contours are denoted by thin black lines and rays are denoted by thick black lines 
traveltime tomography scheme in the presence of irregular surface (Ma and Zhang 2013b). Where, the forward modeling of first arrival traveltime uses the topography-dependent eikonal equation (Lan and Zhang 2013a), and ray path calculation uses the tracking scheme developed by Ma and Zhang (2013a) with irregular surface.

\section{Upper crust structure along Jingtai-Hezuo profile}

The first-arrival traveltime data of this $430 \mathrm{~km}$-long wideangle seismic profile between Alax and Hezuo was interpreted with the traditional way where topography is dealt with model expansion scheme (Fig. 2a) (Zhang et al.
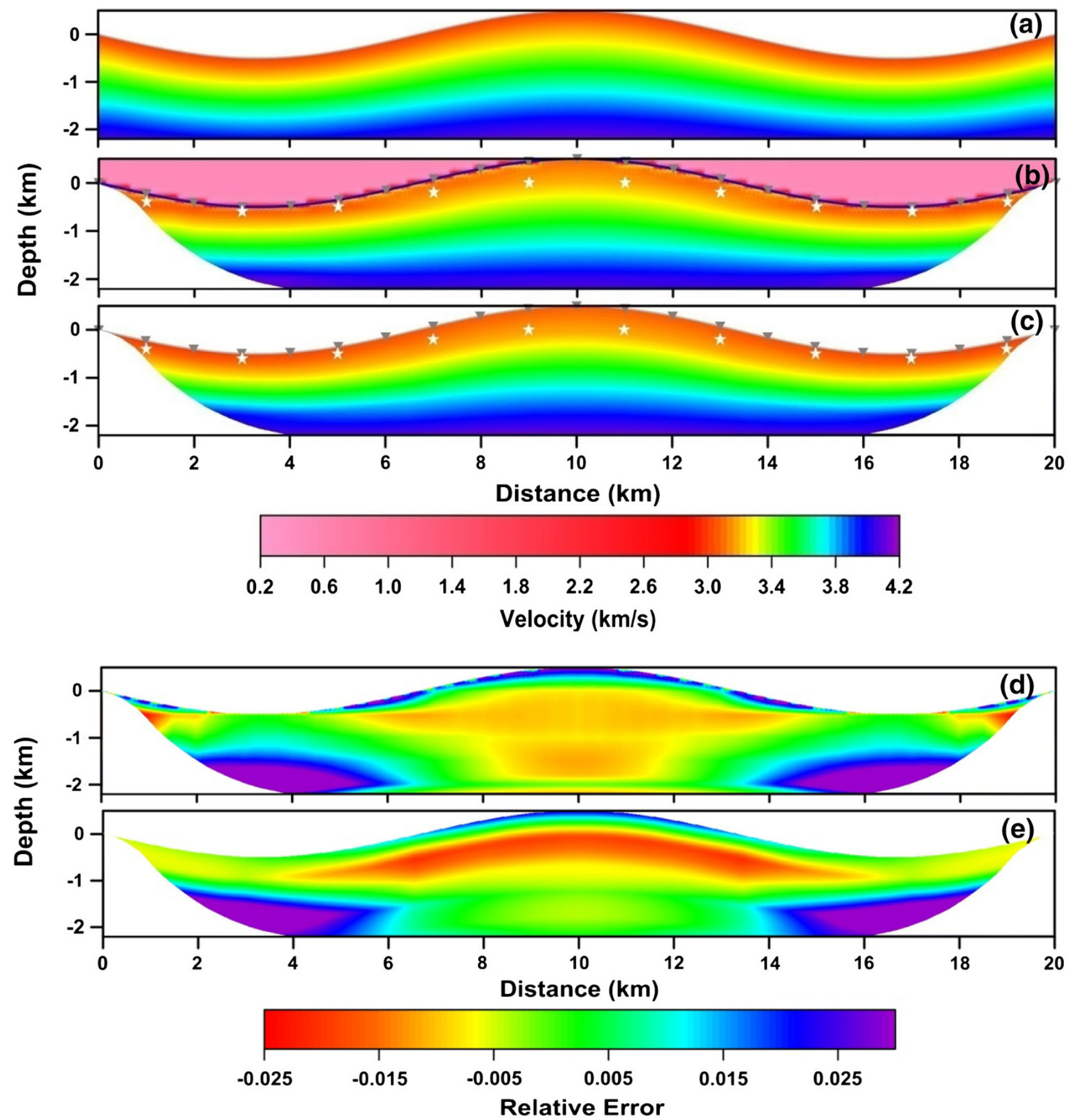

Fig. 6 a Synthetic velocity model. b Tomography result calculated by scheme of Hole (1992). c Tomography result calculated according to topography-dependent eikonal traveltime tomography. The dark blue line denotes the irregular surface. The white stars denote the sources, and the inverted gray triangles denote the receivers located on the irregular surface. d Relative error of synthetic model for scheme of Hole (1992). e Relative error of synthetic model for topography-dependent eikonal traveltime tomography 
2013). Here, we will make reinterpretation of these Pg traveltime dataset with the updated topography-dependent eikonal traveltime tomography scheme (Ma and Zhang 2013b).

To assess the feasibility of topography-dependent eikonal traveltime tomography method, we carried out a synthetic model test. The surface of the model represents topography that combines one hill and two depressions and the model uses continuous medium. The spacing size of the grids is $0.1 \mathrm{~km}$. The starting velocity model uses homogeneous velocity model, and the region above the irregular surface is filled with velocity of $0.5 \mathrm{~km} / \mathrm{s}$ for Hole's scheme (1992). Figure 6a displays the synthetic model. The resultant upper crustal structures from the Hole's scheme and our scheme are presented in Fig. 6b, c, respectively. Most portions of the synthetic model are well recovered both by topography-dependent eikonal traveltime tomography (Fig. 6e) and Hole's scheme (1992) (Fig. 6d). Relative error from topography-dependent eikonal traveltime tomography (Fig. 6e) is reduced compared with errors from Hole's scheme (1992) (Fig. 6d) at the top and bottom of the model in our study, which is inferred partly from improvement of the ray path with irregular surface (by topography-dependent scheme), but more models are needed to make comparison in future. Precision in forward traveltime calculation in our topog- raphy-dependent eikonal traveltime tomography strongly depends on grid size, topography gradient, and velocity distribution, which should be improved to be automatically adjusted during the inversion process (velocity distribution update).

In interpretation of the picked $\mathrm{Pg}$ arrivals in this experiment (Zhang et al. 2013), our upper crustal model is discretized by grids with spacing size of $0.5 \mathrm{~km}$. Upper panel in Fig. 7 shows real topography approached with the boundary-conforming grid. We utilized initial (starting) velocity model with linearily continuous increased velocity (from 5.0 to $6.2 \mathrm{~km} / \mathrm{s}$ ) in both inversion schemes. In order to utilize the scheme of Hole (1992), we constructed a regular model by filling the region above the irregular surface with very low P-wave velocity of $0.5 \mathrm{~km} / \mathrm{s}$.

Figure 8 show the relevant results of tomography beneath the wide-angle seismic profile. The ray paths are comparable with topography-dependent eikonal traveltime tomography (upper panel in Fig. 8a) and Hole (1992) (lower panel in Fig. 8a). The numbers of rays intersecting each cell for these two methods are shown in Fig. 8b. The ray coverage is also similar for these two methods, and the ray coverage for topography-dependent eikonal traveltime tomography (upper panel of Fig. 8b) is a little more uniform, which is one way to improve resolution, even though the resolution can be evaluated with

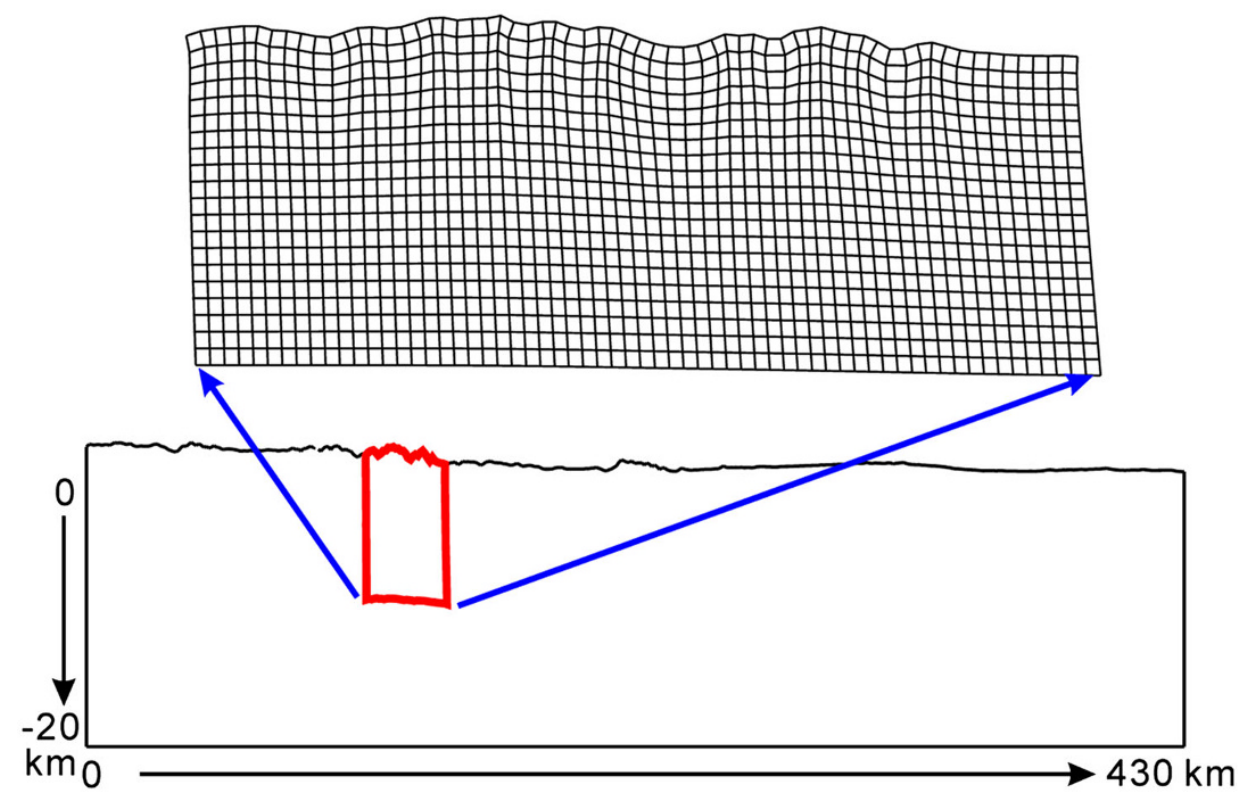

Fig. 7 Upper crustal model and boundary-conforming grid of the wide-angle profile between Alax and Hezuo for topography-dependent eikonal traveltime tomography. Lower panel The model area for constructing upper crustal structure, which was compressed to $20 \%$ along $x$-direction in order to save space; Upper panel For clarity, the grids with red frame are displayed 


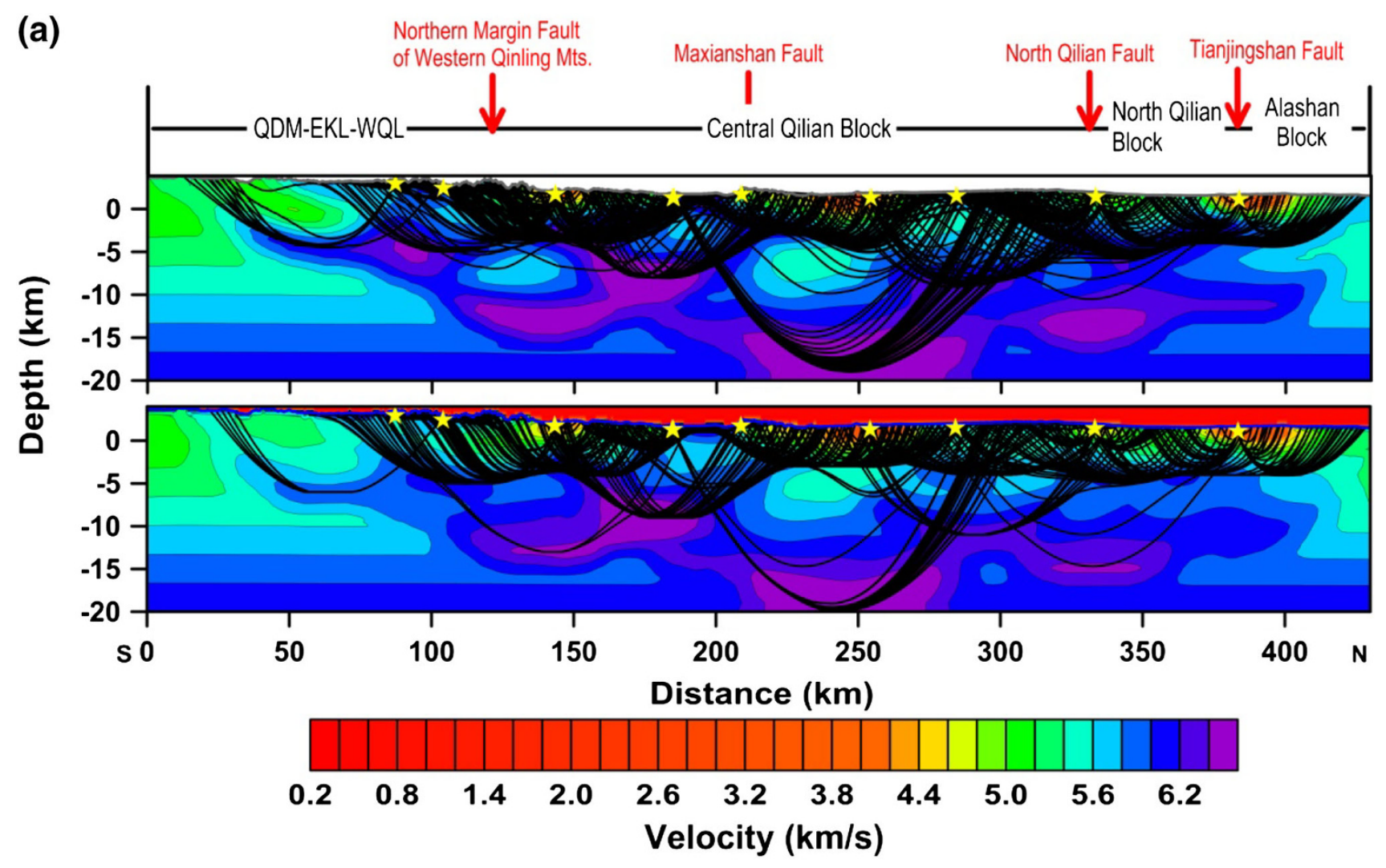

(b)

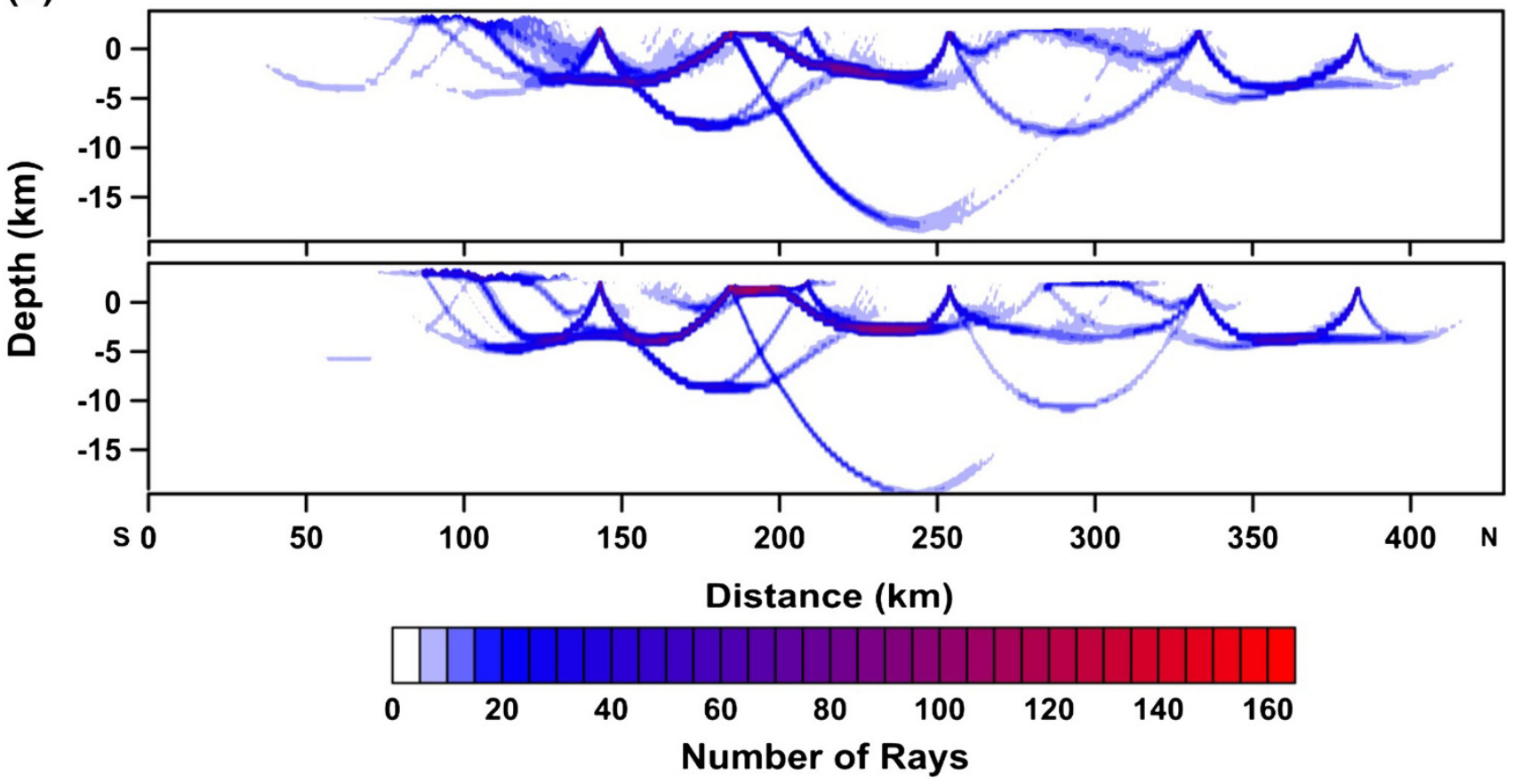

Fig. 8 The wide-angle profile data. a Tomography result and ray paths. Upper panel Topography-dependent eikonal traveltime tomography; Lower panel Traveltime tomography from Hole (1992). b Number of rays intersecting each cell. Upper panel topography-dependent eikonal traveltime tomography; Lower panel Traveltime tomography from Hole (1992) 


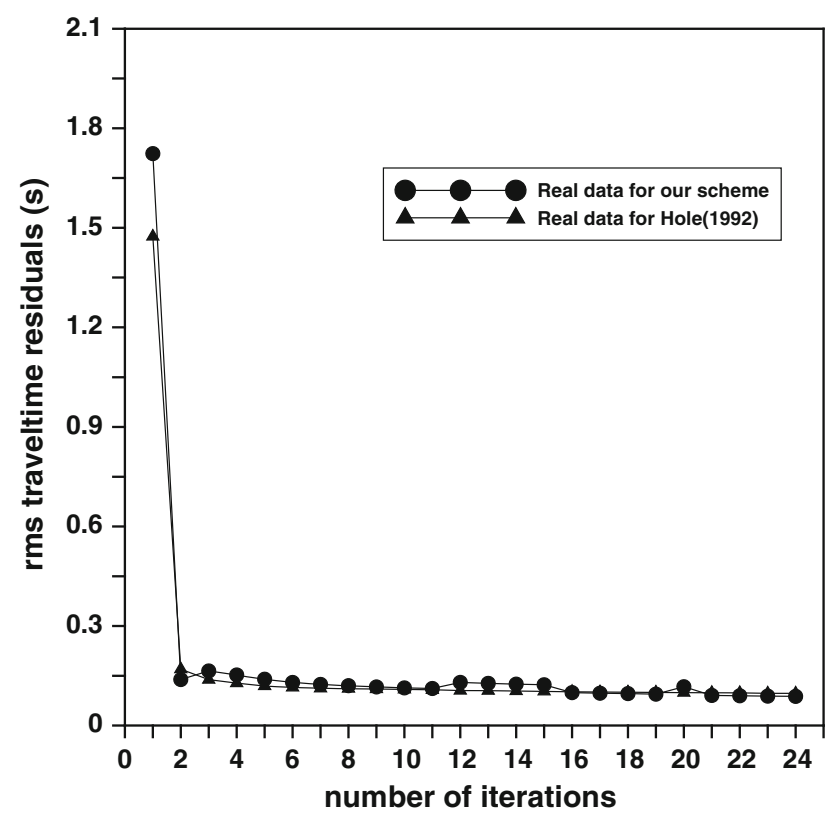

Fig. 9 The rms traveltime residuals plotted against iteration number for the 6th shot of the wide-angle profile data. Circles denote the topography-dependent eikonal traveltime tomography, and triangles denote the Hole's scheme (1992)

checkboard test (Rawlinson et al. 2006) and resolution kernel (Hole 1992).

With two-to-three times updation of the upper crustal velocity model, the rms traveltime residuals for the sixth shot of the wide-angle profile data converge to less than $0.1 \mathrm{~s}$ (Fig. 9) both for topography-dependent eikonal traveltime tomography and Hole's scheme (1992). The upper crustal P-wave velocity structures calculated with topography-dependent eikonal traveltime tomography method and Hole's scheme (1992) are illuminated in Fig. 10a, b, respectively. The top plate in Fig. 10a, b is tectonic setting crossed by the wide-angle profile. We can observe that the low velocity distribution in the sedimentary basins or depressions along the profile. Beneath the segment from the south end of the profile to about $120 \mathrm{~km}$ along the profile (the Qaidam-Eastern Kunlun-West Qinling terrane), sedimentary layer can be divided into southern and northern parts in the upper crustal velocity model. P-wave velocity is $<5.8 \mathrm{~km} / \mathrm{s}$ for the southern part, and about $6.0 \mathrm{~km} / \mathrm{s}$ for the northern part. Within the segment between 120 and $300 \mathrm{~km}$ on the profile (upper panel of Figs. 8a, 10a), the Central Qilian orogenic belt (CQ), was separated into south and north by the boundary of Maxianshan fault. Beneath the southern part, the sedimentary layer has P-wave velocity $<5.0 \mathrm{~km} / \mathrm{s}$, and underlain by a high velocity anomaly about $6.3 \mathrm{~km} / \mathrm{s}$. The segment between 300 and $350 \mathrm{~km}$ on the profile (the Northern Qilian block, NQ), P-wave velocity is less than $5.8 \mathrm{~km} / \mathrm{s}$ for the sediment layer. We recognize that the above analysis is just preliminary and should be improved in future.

\section{Discussion and conclusions}

Free surface is usually irregular and its description of the complicated topography is important for the construction of crustal velocity model. Irregular surface is processed as an inner discontinuity in Hole's tomography scheme (1992) with model expansion scheme, which is due to the stairstep representation of the irregular topography by the rectilinear grids. Here, we present upper crustal P-wave velocity model derived from an alternative scheme, topographydependent eikonal traveltime tomography (Ma and Zhang 2013b), while keeping the irregular surface as free surface, not the inner discontinuity in model expansion scheme. The advantage of using curvilinear grids is that all the surface points may be used as regular grid points. The accuracy of the topography-dependent eikonal traveltime tomography partly depends on the precision in forward traveltime calculation. A high-order eikonal equation solution to the topography-dependent eikonal traveltime tomography should be considered and employed in future.

The model test and real data tomography results show its potential and improvement space for high-resolution reconstruction of upper crustal velocity distribution. We speculate that it needs to take account of the upper crustal P-wave velocity structure to link surface geology and deep geodynamic process in the Northeastern Tibetan plateau. 

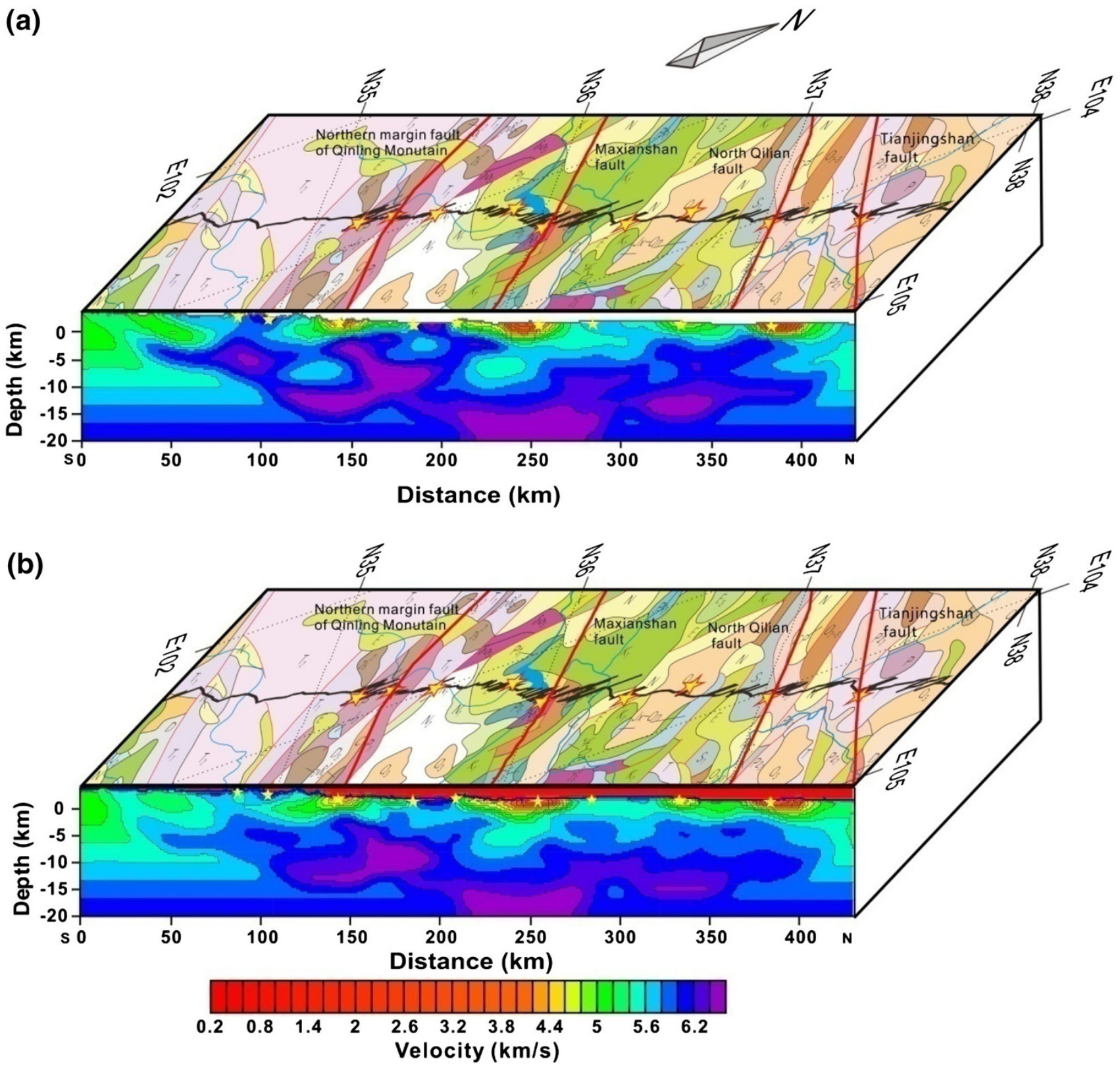

Fig. 10 Tomography results of upper crust along the wide-angle seismic profile. a Tomography result calculated using topography-dependent eikonal traveltime tomography scheme developed in this study; b Tomography result calculated according to Hole (1992). Stars denote source positions. The front Tomography result of upper crustal structure. The top Tectonic setting crossed by the wide-angle profile, and the region is identified by the rectangular regions with the black lines in Fig. 1 . $\mathrm{Pt}_{1}$ : Lower Proterozoic Eonothem, Yemanansha Group; $\mathrm{Pt}_{2}$ : Middle Proterozoic Eonothem; Ch: Middle Proterozoic Eonothem, Changcheng System Danghe Group; Jx: Middle Proterozoic Eonothem, Jixiang System Tuolainansahn Group; Jx-Qn: Upper Proterozoic Eonothem, undivided; $\mathrm{O}_{1}, \mathrm{O}_{2}, \mathrm{O}_{3}$ : Ordovician System, clastic rock and volcanic rock; $\mathrm{S}_{1}$ : Silurian System, flysch and volcanic rock; D: Devonian System, middle-upper series are molasse; $\mathrm{C}_{1}$ : Carboniferous System, marine sediment; P: Permian Marine and continental clastic rock, volcanic rock; $\mathrm{CP}$ : mixed layers including $\mathrm{CP}_{1}, \mathrm{C}_{1} \mathrm{P}$ and $\mathrm{C}_{2} \mathrm{P}_{1} ; \mathrm{Pz}_{2}$ : Upper Paleozoic Eonothem, undivided; $T, \mathrm{~T}_{1}, \mathrm{~T}_{2}, \mathrm{~T}_{2-3}$ : Triassic system, marine flysch and volcanic rock; $\mathrm{J}, \mathrm{J}_{2}, \mathrm{~J}_{3}$ : Jurassic System, mainly continental clastic rock; $\mathrm{K}, \mathrm{K}_{1}, \mathrm{~K}_{2}$ : Cretaceous System, mainly continental clastic rock; $\mathrm{N}, \mathrm{N}_{1}$ : Neogene System, clastic rock and volcanic rock; E, E $\mathrm{E}_{3}$ Paleogene System, mainly clastic rock with volcanic molasse; EN: Paleogene and Neogene System, undivided; $\mathrm{Q}_{3}, \mathrm{Q}_{4}$ : Quaternary System, continental accumulation; $\Sigma_{2}$ : Proterozoic ultra mafic rock; $\Sigma_{3}$ : Caledonian ultra mafic rock; $\gamma \pi_{3}$ : Caledonian granite porphyry; $\gamma_{3}$ : Caledonian granite; $\delta o_{3}$ : Caledonian quartz diorite; $\sigma_{3}^{2}$ : Middle Caledonian peridotite; $\gamma \delta_{5}^{1}$ : Indo-Chinese granodiorite; $\gamma o_{5}^{1}$ : Indo-Chinese tonalite; $\gamma_{5}^{1}$ : Indo-Chinese granite; $\gamma_{5}^{2}$ : Early Yanshanian granite; $\delta o_{5}^{2}$ : Early Yanshanian quartz diorite; $\gamma \delta_{5}^{2}$ : Early Yanshanian granodiorite (from 1:5,000,000 Geological map of China) 
Acknowledgments The authors gratefully acknowledge financial support for this work by the Ministry of Science and Technology of China (2011CB808904), the Ministry of Land and Resources of China (SinoProbe-02-02 or 201011041, SinoProbe-03-02 or 201011047), and the National Nature Science Foundation of China (41174075, 41021063, 41274090 and 41174043).

\section{References}

Argand E, (1924) La tectonique de l'Asie. Conférence faite á Bruxelles, le 10 août 1922. Compte-rendu du XIII ${ }^{\circ}$ Congrès géologique international (XIIIe session)-Belgique 1922, 171-372

Beaumont C, Jamieson RA, Nguyen MH, Medvedev S (2004) Crustal channel flows: 1. Numerical models with applications to the tectonics of the Himalayan-Tibetan orogen. J Geophys Res 109:1978-2012

Burchfiel B, Deng Q, Molnar P, Royden L, Wang Y, Zhang P, Zhang W (1989) Intracrustal detachment within zones of continental deformation. Geology 17:748-752

Burke K, Dewey J (1973) Plume-generated triple junctions: key indicators in applying plate tectonics to old rocks. J Geol 81:406-433

Dewey JF, Shackleton RM, Chengfa C, Yiyin S (1988) The tectonic evolution of the Tibetan Plateau. Phil Trans R Soc Lond A 327:379-413

Dines KA, Lytle RJ (1979) Computerized geophysical tomography. Proc IEEE 67:1065-1073

England P, Houseman G (1986) Finite strain calculations of continental deformation 2. Comparison with the India-Asia collision zone. J Geophys Res 91:3664-3676

England P, Houseman G (1989) Extension during continental convergence, with application to the Tibetan Plateau. J Geophys Res 94:17561-17579

Gan W, Zhang P, Shen Z-K, Niu Z, Wang M, Wan Y, Zhou D, Cheng J (2007) Present-day crustal motion within the Tibetan Plateau inferred from GPS measurements. J Geophys Res 112:B08416

Hole JA (1992) Nonlinear high-resolution three-dimensional seismic travel time tomography. J Geophys Res 97:6553-6562

Humphreys E, Clayton RW, Hager BH (1984) A tomographic image of mantle structure beneath southern California. Geophys Res Lett 11:625-627

Jia S, Zhang X, Zhao J, Wang F, Zhang C, Xu Z, Pan J, Liu Z, Pan S, Sun $G$ (2010) Deep seismic sounding data reveal the crustal structures beneath Zoigê basin and its surrounding folded orogenic belts. Sci China Earth Sci 53:203-212

Klemperer SL (2006) Crustal flow in Tibet: geophysical evidence for the physical state of Tibetan lithosphere, and inferred patterns of active flow. In: Law RD, Searle MP, Godin L (eds) Channel flow, ductile extrusion and exhumation in continental collision zones. Geological Society, Special Publications, London, pp 39-70

Lan H, Zhang Z (2013a) Topography-dependent eikonal equation and its solver for calculating first-arrival traveltimes with an irregular surface. Geophys J Int 193(2):1010-1026. doi:10.1093/gji/ ggt036

Lan H, Zhang Z (2013b) A high order fast sweeping scheme for the computation of first-arrival travel times with an irregular surface. Bull Seismol Soc Am 103:2070-2082. doi:10.1785/0120120199

Li QS, Peng SP, Gao R, Fan JY (2003) Seismic evident of the basement uplift in the Bayan Har tectonic belt, Qinghai, and its tectonic significance. Geol Bull China 22:782-788

Liu M, Mooney WD, Li S, Okaya N, Detweiler S (2006) Crustal structure of the northeastern margin of the Tibetan plateau from the Songpan-Ganzi terrane to the Ordos basin. Tectonophysics 420:253-266
Ma T, Zhang Z (2013a) Calculating the ray paths for first-arrival traveltimes using a topography-dependent eikonal equation solver. Bull Seismol Soc Am, revised manuscript under review

Ma T, Zhang Z (2013b) Topography-dependent eikonal traveltime tomography for upper crustal structure beneath an irregular surface. In prepare

Mattauer M (1986) Intracontinental subduction, crust-mantle décollement and crustal-stacking wedge in the Himalayas and other collision belts. Geol Soc Lond Spec Publ 19:37-50

Métivier F, Gaudemer Y, Tapponnier P, Meyer B (1998) Northeastward growth of the Tibet plateau deduced from balanced reconstruction of two depositional areas: the Qaidam and Hexi Corridor basins, China. Tectonics 17:823-842

Meyer B, Tapponnier P, Bourjot L, Metivier F, Gaudemer Y, Peltzer G, Guo S, Chen Z (1998) Crustal thickening in Gansu-Qinghai, lithospheric mantle subduction, and oblique, strike-slip controlled growth of the Tibet plateau. Geophys J Int 135:1-47

Molnar P, Lyon-Caen H (1988) Some simple physical aspects of the support, structure, and evolution of mountain belts. Geol Soc Am Spec Pap 218:179-208

Molnar P, Tapponnier P (1978) Active tectonics of Tibet. J Geophys Res (1978-2012) 83:5361-5375

Molnar P, England P, Martinod J (1993) Mantle dynamics, uplift of the Tibetan Plateau, and the Indian monsoon. Rev Geophys 31:357-396

Nolet G (ed) (1987) Seismic tomography: with applications in global seismology and exploration geophysics. D. Reidel, Norwell

Owens TJ, Zandt G (1997) Implications of crustal property variations for models of Tibetan Plateau evolution. Nature 387:37-43

Paige CC, Saunders MA (1982) LSQR: an algorithm for sparse linear equations and sparse least squares. ACM Trans Math Softw 8:43-71

Peterson JE, Paulsson BNP, McEvilly TV (1985) Application of algebraic reconstruction techniques to crosshole seismic data. Geophysics 50:1566-1580

Rawlinson N, Reading AM, Kennett BLN (2006) Lithospheric structure of Tasmania from a novel form of teleseismic tomography. J Geophys Res 111:B02301. doi:10.1029/2005JB003803

Reshef M (1991) Depth migration from irregular surfaces with depth extrapolation methods. Geophysics 56:119-122

Royden LH, Burchfiel BC, van der Hilst RD (2008) The geological evolution of the Tibetan Plateau. Science 321:1054-1058

Scales JA (1987) Tomographic inversion via the conjugate gradient method. Geophysics 52:179-185

Song S, Zhang L, Niu Y, Su L, Song B, Liu D (2006) Evolution from oceanic subduction to continental collision: a case study from the Northern Tibetan Plateau based on geochemical and geochronological data. J Petrol 47:435-455

Tapponnier P, Meyer B, Avouac JP, Peltzer G, Gaudemer Y, Guo S, Xiang H, Yin K, Chen Z, Cai S, Dai H (1990) Active thrusting and folding in the Qilian Shan, and decoupling between upper crust and mantle in northeastern Tibet. Earth Planet Sci Lett 97:382-403

Tapponnier P, Xu Z, Roger F, Meyer B, Arnaud N, Wittlinger G, Yang J (2001) Oblique stepwise rise and growth of the Tibet Plateau. Science 294:1671-1677

Tian X, Zhang Z (2013) Bulk crustal properties in NE Tibet and its implication for deformation model. Gondwana Res 24:548-559

Vidale JE (1988) Finite-difference calculation of travel times. Bull Seismol Soc Am 78:2062-2076

Vidale JE (1990) Finite-difference calculation of traveltimes in three dimensions. Geophysics 55:521-526

Wang YX, Mooney WD, Han GH, Yuan XC, Jiang M (2005) Crustal P-Wave Velocity Structure from Altyn Tagh to Longmen Mountains along the Taiwan-Altay Geoscience Transect. Chin J Geophys 48:116-124 (in Chinese with English abstract) 
Wei C, Yang Y, Su X, Song S, Zhang L (2009) Metamorphic evolution of low-T eclogite from the North Qilian orogen, NW China: evidence from petrology and calculated phase equilibria in the system NCKFMASHO. J Metamorph Geol 27:55-70

Xiao W, Windley BF, Yong Y, Yan Z, Yuan C, Liu C, Li J (2009) Early Paleozoic to Devonian multiple-accretionary model for the Qilian Shan, NW China. J Asian Earth Sci 35:323-333

Xu ZQ, Yang JS, Zhang JX (2001) Tectonic evolution and lithospheric shearing in the Altun Mts. and Qilian Mts. Research Report, Institute of Geology, Chinese Academy of Geological Sciences (in Chinese, unpublished)

Yang J, Xu Z, Li H, Wu C, Cui J, Zhang J, Chen W (1998) Discovery of eclogite at northern margin of Qaidam Basin, NW China. Chin Sci Bull 43:1755-1760

Yang J, Xu Z, Zhang J, Song S, Wu C, Shi R, Li H, Brunel M (2002a) Early Palaeozoic North Qaidam UHP metamorphic belt on the north-eastern Tibetan plateau and a paired subduction model. Terra Nova 14:397-404

Yang W, Deng Q, Wu X (2002b) Major characteristics of the Lajishan orogenic belt of the South Qilian Mountains and its geotectonic attribute. Acta Geologica Sinica (English Edition) 76:110-117

Yin A (2010) Cenozoic tectonic evolution of Asia: a preliminary synthesis. Tectonophysics 488:293-325

Yin A, Harrison TM (2000) Geologic evolution of the HimalayanTibetan orogen. Annu Rev Earth Planet Sci 28:211-280
Yin A, Dang Y, Zhang M, McRivette MW, Burgess WP, Chen X (2007a) Cenozoic tectonic evolution of Qaidam basin and its surrounding regions (part 2): wedge tectonics in southern Qaidam basin and the Eastern Kunlun Range. Geol Soc Am Spec Pap 433:369-390

Yin A, Manning CE, Lovera O, Menold CA, Chen X, Gehrels GE (2007b) Early Paleozoic tectonic and thermomechanical evolution of ultrahigh-pressure (UHP) metamorphic rocks in the northern Tibetan Plateau, northwest China. Int Geol Rev 49:681-716

Zhang Z, Yuan X, Chen Y, Tian X, Kind R, Li X, Teng J (2010) Seismic signature of the collision between the east Tibetan escape flow and the Sichuan Basin. Earth Planet Sci Lett 292:254-264

Zhang Z, Yang L, Teng J, Badal J (2011) An overview of the earth crust under China. Earth Sci Rev 104:143-166

Zhang Z, Bai Z, Klemperer SL, Tian X, Xu T, Chen Y, Teng J (2013) Crustal structure across northeastern Tibet from wide-angle seismic profiling: constraints on the Caledonian Qilian orogeny and its reactivation. Tectonophysics. doi:10.1016/j.tecto.2013. 02.040

Zhao WL, Morgan WJ (1985) Uplift of Tibetan plateau. Tectonics 4:359-369

Zhao W, Nelson KD (1993) Deep seismic reflection evidence for continental underthrusting beneath southern Tibet. Nature 366:557-559 